PART 1

State Impositions and Passive Acceptance 
Saki Murakami - 9789004280724

Downloaded from Brill.com04/26/2023 05:48:28AM via free access 


\title{
Call for Doctors!
}

\author{
Uneven Medical Provision and the Modernization of State \\ Health Care during the Decolonization of Indonesia, 1930s-1950s ${ }^{1}$
}

\author{
Saki Murakami
}

\section{Introduction}

The prolonged period of war, which had begun with the Japanese invasion in 1942 and ended with the transfer of sovereignty in 1949, had an enormously destructive impact on the economy (Booth 1987:10). As this decolonization process had been fuelled by 'anti-colonial' feelings, the remaining nonIndonesian element had, if possible, to be replaced by Indonesians; this meant a structural change in most of the modern sectors of the economy and the state apparatus after 1949 (Lindblad 2008). However, 'anti-colonial' did not necessarily mean 'anti-modern' and opposition to the modern advances, which had come with the last phase of colonialism. On the contrary, more modernization, or the equal distribution of modernity of the late-colonial society to non-European segments of the society, was one of the nationalists' objectives.

Two related objectives, political decolonization and the pursuit of modernity, produced a paradox: the desire to build a newly independent nation-state but with particular 'modern' characteristics adopted from the colonial state. Unquestionably, the most modern sectors tended to be those most dominated by the former colonial overlords and it was these moderns sectors in which decolonization was most urgently needed. This chapter examines one such paradox of decolonization and modernity. I shall describe how the Indonesian national government attempted to decolonize the modern state by taking medical provision in the 1950 s as a case study.

Despite its importance to an understanding of both the process of decolonization and the rise of the succeeding authoritarian state structure in Indonesia, the period of the 1950s has still not been thoroughly discussed for a number of reasons (McVey 1994; Vickers 2005). Especially when compared with issues related to the nation and nation-building, the question how the state was

1 This paper is based on research done with a Scholarship for Studying in Asian Countries, Japanese Ministry of Education, Culture, Sports, Science and Technology from March 2003 to September 2004, and also research done as a Research Fellow of the Japan Society for the Promotion of Science since April 2005. I would like to convey my sincere appreciation here.

(C) SAKI MURAKAMI, 2015 | DOI 10.1163/9789004280724_003

This is an open access chapter distributed under the terms of the Creative Commons Attribution- 
(re-)established has been less well explored (Schulte Nordholt 2004). Health forms an important entry point for such an inquiry into the state.

The collective treatment of diseases had only become a function of the state quite recently, preponderantly during the latter half of the nineteenth century, in step with the development in modern biomedicine. In practice, this collective treatment in Indonesia has been dominated by modern medicine both before and after Independence. As will be shown, the newly independent nation-state pursued the standardization of public health care throughout the archipelago for two reasons: to enhance its standing externally and to build national solidarity. The rub was that this function of the state required scientific expertise and this had been dominated by the Dutch colonizers. In the process of decolonization they had to be replaced. In this respect, health can provide important insight into the complex nature of decolonization of the modern state.

The standardization, or equal distribution, of health care throughout Indonesia was composed of two elements: medical provision pure and simple and the nation-wide imposition of sanitary regulations. My choice has been to focus on medical provision, the appointment of new medical personnel and in particular doctors, throughout Indonesia as one of the tasks of public health administration. This is a convenient topic of study because the national elite in the public health sector made public statements on the matter and also the opinion of the general public made itself heard, in their demands made in printed mass media. The national elite in the health sector was characterized by a strong nationalistic predisposition and, as health was unquestioningly seen as beneficial, its members publicly demanded the standardization of proper medical provision in all regions of Indonesia and in all layers of society. Although the development of medical institutions and the provision of drugs were equally as important as the provision of medical staff, they are less suited to analysis as such research is hampered by the scarcity of reliable sources on these other important health-care issues.

The first section gives a picture of colonial medical provision: how did it begin, who were the personnel, and how were they distributed? After an examination of the complexity of providing medical personnel, a panoramic view of their distribution will be given. In the second section I shall discuss how national leaders, in attempts to distinguish themselves from their colonial predecessors, fostered health for the whole nation by instigating many projects to promote rural public health. Unfortunately, the number of human resources necessary to achieve this goal at the time was inadequate. The first state effort to solve the scarcity of medical staff in certain areas consisted of regulations designed to control the distribution of medical personnel. In the third section, 
I shall argue that the legislation process failed to give due consideration to the complex demands, and thereafter show that the prescriptions on how to distribute medical personnel failed to have any real effect on the equal distribution of staff. The fourth section looks at the way government efforts concentrated on doctors, ignoring any attempts to expand the number of other qualified medical personnel in the short run as an alternative means to correct the structural dearth. Ultimately the shortage of medical personnel was not solved. The last section demonstrates that the inability or unwillingness of the government to change the situation was not criticized publicly by the population. Instead, public requests and complaints turned against individual doctors, putting moral pressure on them; these public demands in turn were seized upon to legitimize greater state control of medical personnel.

\section{Colonial Medical Provision: Its Priorities and Geographical Distribution}

Medical provision and health administration in general began to be institutionalized at the beginning of the twentieth century keeping pace with the general development of medical science, the expansion of both the European population and Western enterprise in the colony, the ravage wrought by several epidemic diseases, and the expansion of missionary activities. Up to the end of nineteenth century, medical institutions were pretty much limited to the military. The Burgerlijke Geneeskundige Dienst (BGD, Civil Medical Service) was subordinated to the Militaire Geneeskundige Dienst (MGD, Military Medical Service) until 1911 and military doctors were also expected to provide medical care for civil servants. By the turn of the century, this system was considered inadequate and inefficient, and voices were raised arguing for the need for a proper institution to provide medical care for the civilian population. Just at this time, private institutions also commenced undertaking medical work. Missionary doctors began to build a network of hospitals and clinics. Plantation companies in East Sumatra issued sanitary regulations and organized medical provision for their employees. Their successes made other companies realize the benefits in labour control, eventually even pushing the government to institutionalize public health care (Murakami 2003: 4-11).

The 1906 Subsidy for Private Hospitals Act paved the way for the granting of subsidies to private hospitals, allowed the purchase of land for the construction of hospitals, and regulated the management of indigenous patients or those who were entitled to free medicine (Indisch Staatsblad 1906/276). In the same year, the Commissie tot Voorbereiding eener Reorganisatie van den 
Burgerlijken Geneeskundigen Dienst (Commission Preparing a Reorganization of the BGD) was constituted. At this point, the BGD had very few staff members of its own. It consisted of three Inspectors at the central level and 164 doctors at the local level in Java (Rapport der Commissie 1908:225-237). On the recommendation of the Commission, the Regulation governing the BGD was revised, making it fully independent of the Military Medical Service, assigning it a larger budget and eight staff members at the central level, including a director as of 1910 (Indisch Staatsblad 1910/648; Koloniaal Verslag 1911:147).

Soon after this reorganization, the BGD expanded rapidly because it was required to take measures to control the dreaded plague in 1911. The second Director of the BGD, Dr W.T. de Vogel, was convinced that preventive medicine was a prime state function, but actual medical provision should be entrusted to private institutions and local governments. ${ }^{2}$ The BGD followed this idea and transformed itself into the Dienst der Volksgezondheid (DVG, Public Health Service) in 1924. Even at that time, De Vogel foresaw the need to expand Western medical provision, primarily to make it easy to supervise the medical conditions, but he was also concerned with changing people's sanitary habits (De Vogel 1917:7-12). With these requirements in mind, the central government continued to provide subsidies and to put its staff at the disposal of local governments and private institutions.

The negative corollary of the state priority accorded to preventive medicine, especially the control of epidemics, was the lack of attention paid to the medical providers. As a consequence, the actors in the health service were diverse. On the basis of the prevailing financial and management structure, medical institutions in the Netherlands Indies were divided into ten categories. In 1939 there were six central government hospitals, two provincial government

2 Dr Willem Thomas de Vogel (1863-1955), who had a Eurasian background, studied medicine in both Leiden and Berlin. He was active in the administration as well as in the academic field. He played an important role in the expansion of the city area of Semarang as a member of the newly founded Municipal Council of Semarang in 1906. He was also active in the Bond van Nederlandsch-Indische Artsen (Association of Doctors in the Netherlands Indies), which played a role in pushing the government to reorganize the BGD systematically rather than simply by essaying a haphazard expansion of medical provision. In 1907 he co-founded the Nederlandsche Vereeniging voor Tropische Geneeskunde (Dutch Society for Tropical Medicine) and maintained a strong connection with the newly established Instituut voor Tropische Hygiëne (Institute of Tropical Hygiene) of the Koloniaal Instituut (Colonial Institute) in Amsterdam. He investigated the plague in Malang, malaria in Sibolga, as well as health problems in a more general sense. After retirement as the Director of BGD in 1921, he represented the Netherlands Indies government at the Office International d'Hygiene Publique at Paris until the outbreak of the Second World War. 
hospitals, one other local government hospital with a subsidy, 60 unsubsidized hospitals, 62 hospitals in semi-autonomous indigenous states, 95 subsidized private hospitals, seventeen contract hospitals in semi-autonomous indigenous states (which were compensated for treating poor patients by the central government), 34 private contract hospitals, two contract hospitals under the auspices of other government services, and 238 unsubsidized private hospitals (Indisch Verslag 1940, II:80). Besides these hospitals, a growing number of clinics was set up and then there were doctors with a private practice. Most government doctors ran a private practice in their spare time to supplement their salary.

Not only hospitals, but also doctors were firmly placed into various categories. Legally, civil medical practitioners in modern Western medicine (doctors or geneeskundigen) were divided into two categories: those educated in medical faculties at university level with the Dutch title of arts and those educated in the colonial medical school with the title of Dokter-Djawa (Javanese Doctor) and later Inlandsche arts (Indigenous Doctor). When the first European doctors arrived in the Indonesian archipelago, the title 'arts' was not yet legally protected and medical qualifications in the motherland were still diverse. At that time, most doctors from Europe were surgeons. In the nineteenth century, most of the civilian doctors or doctors with a private practice had been retired military doctors. In the Netherlands, qualifications approved and protected by the central government were established in the medical reforms of 1865 , and this qualification was also followed in the colony (Querido 1968:13-16, 31-33).

The establishment of the Dokter-Djawa School as a government response to the famine and the smallpox epidemics in the middle of the nineteenth century meant that medical education preceded the general institutionalization of health administration in the Netherlands Indies. Even after the foundation of the Dokter-Djawa School, medical personnel continued to be scarce throughout the nineteenth century: on average one civil doctor (whether he was a private doctor, medical officer working for the $\mathrm{BGD}$, or a Javanese Doctor) to around 180,000 persons. ${ }^{3}$

Gradually, because of the continuing scarcity of Javanese doctors and the high cost of recruiting European doctors, medical education in the colony was extended both in length of time and quality and was opened to other ethnic groups. In 1901 the Dokter-Djawa School was renamed School tot Opleiding van Inlandsche Artsen (stoviA, School for the Education of Indigenous Doctors). With this change, the title of Dokter-Djawa became Inlandsche arts (and later

3 This calculation is based on Koloniaal Verslag (1854, 1896); and Boomgaard and Gooszen (1991:128-137). 
Indische arts), and the salary and status of this category of doctors were raised. In 1913, the Nederlandsch Indische Artsenschool (NIAS, Netherlands Indies Doctors' School) was established in Surabaya. As was the SToviA in Batavia, it was financed and supervised by the central government. This expansion of the education of indigenous doctors followed the recommendations of the Commission Preparing a Reorganization of the BGD (Rapport der Commissie 1908:26). Soon after its new rival in Surabaya had opened its doors, sT Ovia followed the example of NIAS and accepted non-indigenous students as well. Besides attending medical schools in the colony, even before the turn of the century indigenous and other Asian students began to study in Europe in order to obtain the title of arts.

Despite the upgrading of the Dokter-Djawa School to stovia and NIAS, Indische artsen were clearly distinguished from European-educated doctors bearing the title of arts in salary and status. On the initiative of Abdul Rivai, member of the Volksraad (consultative house of representatives), sTOVIA was transformed into the Geneeskundige Hoogeschool (GHS) in 1927. The GHS offered medical education at university level and bestowed the title of arts on its graduates. The fact that, in contrast to GHS, NIAS continued to produce graduates with the title of 'Indische arts' and was dominated by indigenous students was perceived by indigenous doctors as a persistent racial discrimination (VIG 1939).

The education of auxiliary medical personnel was never formally or centrally institutionalized in colonial Indonesia. Mantri perawat or djuru rawat acted as (male) nurses in hospitals or as basic medical providers at clinics under the supervision of a doctor who visited the establishment several times a week. The impetus to train auxiliary medical personnel came from missionaries who began to develop networks consisting of one hospital with a doctor at the centre and clinics headed by mantri perawat in the periphery. Mantri perawat were trained by the hospitals that employed them; they were not allowed to provide independent medical care. This non-standardized and decentralized training was in sharp contrast to the education of doctors, which was tightly state-controlled.

Meanwhile, most of the indigenous population continued to use indigenous traditional healers to cure their ailments. It seems that the colonial government almost totally ignored them. De Vogel vehemently rejected indigenous medicine as unscientific and judged the efficacy of traditional medical practitioners in confronting the cholera epidemic in 1908/o9 disappointing (Handelingen Volksraad 1921:89o). Even though there were several studies of traditional medical practices and also calls for more thorough research, especially from Indische artsen, traditional medicine was clearly considered something to be studied rather than to be institutionalized (Astrohadikoesoemo 
1940; Margoendiningrat 1940). Only traditional midwives attracted some interest, but only in as far as they could be supervised and utilized by offering them some short courses in hygiene.

On their side, traditional medical providers put up neither an organized reaction to the ignorance of the government nor made any kind of effort to modernize their own system, as happened in India, China, or in Japan. ${ }^{4}$

By the end of the colonial period, the Netherlands Indies had 1,400 doctors in total, supplemented by 211 European nurses and 1860 mantri perawat (Indisch Verslag 1941, II:78-79). Examining the distribution over the Residencies, we note that private doctors, who made up more than half of all the doctors, were concentrated mostly in Java and in some other centres of Western enterprise. Although government doctors were found throughout the Archipelago, the number of people per doctor varied enormously according to place. Dr P. Peverelli, the Director of the Municipal Health Service of Batavia, gave figures on the medical provision in each of twenty-six city municipalities in around 1937. It shows that 458 doctors ( 33 per cent of all doctors) were settled in autonomous municipalities (Peverelli 1938:6-8). The comparison between municipalities and the rural areas of the Residencies in which the municipalities were situated reveals a large urban-rural difference in medical provision (Table 2.1).

Of course, not everybody actually visited doctors to seek a remedy. A high number of persons per doctor, such as in the Residency of Buitenzorg outside the municipalities, was not an indication that many people shared one doctor, but conversely that the majority did not have a chance to see a doctor at all. Hence the differential access to medical care was even starker than Table 2.1 suggests.

Besides urban-rural differences and the huge discrepancies between Residencies (especially in the rural areas of these), we can also observe a relatively plentiful medical provision in some parts of the Outer Islands. As the colonial government was happy to allow private actors the lion's share of the provision of medicine there, more doctors were concentrated in centres of economic activity. Consequently, besides churches or other charitable institutions, planters, plantations, and mining companies had been important private actors employing medical doctors. Certainly, the companies could restrict the medical care to their company employees, but this was not always the case. They sometimes offered their medical personnel to the government to

4 Huard, Bussy and Mazars 1991:128-131, 226-241; Hashimoto 2003:113-120. This lack of action might be explained by the comparative lack of theoretical sophistication of the healers. Peter Boomgaard (1996:53-57) found that, compared to their equivalents in continental Asia, Indonesian indigenous traditional healers used more local knowledge and were little affected by influence from (other Asian) regional or naturalistic medical systems. 
TABLE 2.1 Number of persons per doctor in urban and rural areas, around 1938

\begin{tabular}{|c|c|c|c|c|}
\hline Residency & $\begin{array}{l}\text { Municipality } \\
\text { within residency }\end{array}$ & $\begin{array}{l}\text { Persons per } \\
\text { doctor in the } \\
\text { whole residency }\end{array}$ & $\begin{array}{l}\text { Persons per } \\
\text { doctor in the } \\
\text { municipality }\end{array}$ & $\begin{array}{l}\text { Persons per } \\
\text { doctor in the } \\
\text { residency } \\
\text { without } \\
\text { municipality }\end{array}$ \\
\hline Batavia & Batavia & 9,384 & $4,5^{22}$ & 12,753 \\
\hline Buitenzorg & $\begin{array}{l}\text { Buitenzorg, } \\
\text { Soekaboemi }\end{array}$ & $5^{8,237}$ & 4,185 & 190,909 \\
\hline Priangan & Bandoeng & 26,529 & 3,029 & $5^{2,303}$ \\
\hline Cheribon & Cheribon & 98,557 & 5,778 & 168,141 \\
\hline Pekalongan & Pekalongan, Tegal & 101,543 & $8,5^{8} 3$ & 181,223 \\
\hline Semarang & Semarang, Salatiga & 26,243 & 6,306 & 43,748 \\
\hline Kedoe & Magelang & 87,480 & $14,75^{\circ}$ & 99,117 \\
\hline Soerabaja & $\begin{array}{l}\text { Soerabaja, } \\
\text { Modjokerto }\end{array}$ & 14,907 & 5,405 & 24,673 \\
\hline Malang & Malang & 42,171 & 3,333 & 75,460 \\
\hline Kediri & Blitar & 96,448 & 12,400 & 117,460 \\
\hline Madioen & Madioen & 123,034 & 7,833 & 192,155 \\
\hline Besoeki & $\begin{array}{l}\text { Probolinggo, } \\
\text { Pasoeroean }\end{array}$ & 90,579 & 12,000 & 118,312 \\
\hline $\begin{array}{l}\text { Sumatra's } \\
\text { Oostkust }\end{array}$ & $\begin{array}{l}\text { Medan, Bindjei, } \\
\text { Pematang Siantar }\end{array}$ & 16,932 & 3,467 & 22,703 \\
\hline Sumatra's & Fort de Kock, Sawah & 59,697 & 3,000 & 81,883 \\
\hline Westkust & Loento & & & \\
\hline Palembang & Palembang & 37,887 & 12,111 & 49,486 \\
\hline Manado & Manado & 49,507 & 6,600 & 61,425 \\
\hline Celebes & Makassar & 77,331 & 8,000 & 100,442 \\
\hline Molukken & Ambo & $25,5^{26}$ & 5,000 & $27,45^{\circ}$ \\
\hline $\begin{array}{l}\text { Netherlands } \\
\text { Indies (total) }\end{array}$ & & 41,480 & 5,085 & $5^{8,275}$ \\
\hline
\end{tabular}

SOURCE: NUMBER OF PERSONS PER DOCTOR CALCULATED ON THE BASIS OF INDISCHE VERSLAG $(1938,1941)$ AND PEVERELLI $(1938: 6-8)$. 
facilitate medical care for the surrounding areas, set up hospitals accessible for the neighbouring population, financed medical institutions of churches, or joined other local actors to provide medical care. ${ }^{5}$

Unquestionably, indigenous economic activity often did not lag far behind the large Western enterprises in the Outer Islands, and their activity also affected health provision. Indigenous smallholder production of export crops had developed rapidly in the Outer Islands at the beginning of the twentieth century and made up about one-third of all exports in 1929 (Booth 1990:200202). Rubber production led the way. Taxes collected on the basis of the rubber restriction scheme set up by the International Rubber Agreement of 1934 were often used for medical care in areas were smallholder rubber proliferated. ${ }^{6}$ Therefore, the uneven distribution of medical care was not invariably defined by the urban-rural divide, as nationalist leaders were later to allege.

Summing up the colonial situation, we can point out three characteristics of medical care. Firstly, the health administration had become institutionalized with its principal focus on the prevention of infectious diseases; it left the bulk of medical curative care to local or private initiatives (although the state did support these initiatives by granting subsidies). This policy resulted in a great diversity of medical providers and an uneven geographical distribution. Secondly, Western-educated doctors enjoyed the highest status and a concomitant salary. Indigenous doctors had to struggle for a very long time to overcome the inferiority of their qualifications. Thirdly, while the proportion of doctors to the population differed greatly from place to place, the network of both government and private clinics based on Western medicine had penetrated the society to some extent. At least it was not completely alien to the population. After Independence, the nationalist leaders tried to redress these imbalances in care.

\section{Rural Health and the Need to Phase Out Urban-Rural Differences after Independence}

The point of departure for this section is how the 'ideal' national health system and the role of the state in this were imagined by national leaders in the health

5 Though self-gratulatory, Penris' post-war account describes a fair picture of such a practice (Penris 1949). See further, for example, National Archief, The Hague (NA), Memories Ministerie van Koloniën ( $\mathrm{MMK}$ ) 124, Memorie van Overgave (MvO) Resident Bondowoso, C.E. Barre, 1931; NA, MMK 100, MvO Resident Madioen, V. de Leeuw, 1932.

6 See for example, NA, MmK 190, MvO Gouverneur Oostkunst van Sumatra, B.C.C.M. van Suchtelen, 1936; NA, MMK 225, MvO Resident Djambi, Ph. J. van der Meulen, 1936. 
sector. In their policy statements, these leaders publicly advocated 'rural health', that is the concentration of more services in rural areas. In doing so, they often explicitly contrasted this goal with the situation in colonial times. Projects related to 'rural health' necessitated a more even distribution of doctors, but in reality the number of doctors in government service was decreasing, especially among those in rural areas.

In a speech to university students, Dr M. Soetopo criticized the Dutch for their long time tendency to concentrate on cities and explained the 'philosophy of public health' of the new nation. ${ }^{7}$ With these words, Soetopo referred to the directions decided at the Conference of Officials in Yogyakarta in 1947. Health was identified as one of the major requirements in the development of the nation and the state, and a national public health service was said to be essential to secure a healthy and happy life for each national citizen. As this public health service should cover the 'whole of society', as a logical corollary the state should expand its health service to villages (Soetopo 1957:4-6; Harian Umum 17-9-1957).

Dr Leimena, the first Minister of Health after the transfer of sovereignty, was also an advocate of rural health. ${ }^{8}$ He distinguished his national policy from that of the colonial government by emphasizing that the Indonesian government was trying to expand health care to the villages (desa) and he endeavoured to build a health organization, which hinged on rural health. ${ }^{9} \mathrm{He}$ also

7 Dr M. Soetopo obtained the degree of Indische arts from NIAS in 1924 and of arts from G HS in 1936, and went on to enjoy a productive career in both academic and research fields in Surabaya and Batavia. In 1947 he joined the newly formed Ministry of Health in Yogyakarta as Head of the Education Section. He served as Minister of Health in the Halim Cabinet of the Republic of Indonesia, a constituent of the short-lived United States of Indonesia. After the United States of Indonesia had been merged into the unitary state, Soetopo headed the Lembaga Penelitian dan Pembasmian Penjakit Kelamin (Institute for Research into and Eradication of Venereal Diseases) and contributed to the eradication of yaws until his retirement in 1958. After his retirement he remained active in many fields of health and was awarded a Doctor Honoris Causa by the Universitas Airlangga in Surabaya in 1968 (Pidato 1969).

8 Dr J. Leimena, a stovia graduate of 1930, became famous both as a politician and as a technocrat. As a Christian from Ambon, he joined the nationalist movement in the 1920 and became one of the founders of the Partai Kristen Indonesia (Parkindo, Indonesian Christian Party). In colonial times he had worked for Roman Catholic hospitals in West Java. After Independence, he served as Minister of Health for more than twelve years in twelve different cabinets between 1945 and 1959, and thereafter served other Ministers of Health without interruption until 1966. After 1966 Leimena worked for the Department of Health as Advisor for the Minister (Hitipeuw 1986).

9 Arsip Nasional Republik Indonesia, Jakarta (ANRI), Arsip Kabinet Presiden Republik Indonesia (Kabinet President RI) 636, Jawaban atas pertanyaan seksi kesehatan di DPR, 1-8-1951. 
explained at a World Health Organization congress in Geneva that 'since more than 70 per cent of the population in Indonesia lives in rural areas, proper attention has to be paid to the health services there' (Leimena 1953:7). Another influential figure, the Head of Public Health Education, Dr R. Mochtar, commented as he was about to depart to the United States on study leave, that so far health activities had been limited to the cities and after his return, he would like to set himself the task of changing the organization of public health in order to expand health care right down to the level of hamlets (dusun-dusun) (Harian Indonesia 27-9-1950). ${ }^{10}$

This growing interest in rural health was certainly stimulated by the nationalist ideals of standardized services throughout the nation, but international interests and academic trends also had an impact. Public health, developed mostly under urban conditions in Europe in the nineteenth century, had begun to expand to rural areas in the twentieth century, especially after the First World War. When the typhus epidemic in Eastern Europe posed a real menace to public health after the First World War, the League of Nations Health Organization organized the Epidemic Commission and later held the Intergovernmental Conference on Rural Hygiene for European countries in 1931, financed by the Rockefeller Foundation. Japan, China, and India pushed the League of Nations Health Organization to hold a similar congress for Asia, and their demand was realized as the Intergovernmental Conference of FarEastern Countries on Rural Hygiene, held in Batavia in 1937 (LNHO 1937; Dubin 1995; Balińska 1995).

Even before that intergovernmental conference, in 1924 the Netherlands Indies government had already commenced rural health care activities with the assistance of the Rockefeller Foundation. In 1935 the regentschap (district) Purwokerto was designated to become a model and training field for rural health staff.

In the theory of public health, of which the roots were in the United States, preventive medicine and curative medicine were strictly segregated fields in both budget and personnel. Dr Hydrick, an American doctor dispatched to Indonesia by the Rockefeller Foundation, basically stuck to this principle in his own project but the 1937 Intergovernmental Conference concluded that the integration of preventive and curative medicine was sometimes unavoidable if success was to be achieved (Hydrick 1937; LNHO 1937:3-15). Debating the tasks After Independence he served as the Head of Public Health Education until 1957 (Gunseikanbu 1944:330-331; Mochtar 1954). 
of district doctors, indigenous doctors also considered a model in which both preventive and curative medicine were integrated in the person of the district doctor more realistic. They felt they should personally take the initiative in this respect (Mochtar 1938:55; Zahar 1938:60-67; Soemedi 1940). This tendency towards integrated rural health programmes was continued into the post-war period through a WHO initiative (Leimena 1955a:19; 1955b:6-7).

Against this background of the standardization of urban and rural health care as a national and nationalist ideal, the continuities in pre-war health care concepts and personnel, and international assistance, three model plans were developed to make 'rural health' an attainable goal. The first of these was the Bandung Plan, followed by the Purwokerto Project and finally the Bekasi Project.

The Bandung Plan was a project, which was modelled on the missionary method of a network consisting of a central hospital and dependent small clinics. The project pursued the aim of the 'integration' of preventive and curative medicine. This project, first initiated by the municipal government of Bandung in 1950, was strongly pushed by Dr Leimena who aimed to launch it in 1951. Under this project, both the urban and the rural area of Bandung, administratively different areas but bearing the same name, acquired more medical facilities financed by the central government (Harian Indonesia 21-7-1950; Antara 17-12-1953; Antara 1-6-1956).

In Central Java the Purwokerto Project, begun in the colonial period, was extended by the above-mentioned Dr R. Mochtar to the whole of Banyumas (of which Purwokerto is part), Yogyakarta, and Magelang. He, as had Dr Hydrick before him, emphasized the importance of health Education and the deployment of educated hygienists (djuru hygiene) in order to construct a hygiene organization from the district level down to the villages (Mochtar 1954).

The Bekasi Project was commenced in 1956 by the Division of Rural Health and Health Education of the Ministry of Health, headed by Dr Sulianti Saroso. ${ }^{11}$ The project received assistance from USAID (finance and staff), wHO (staff), and UNICEF (equipment) and it was carried out in rural areas in the vicinity of the national capital, Jakarta. This project highlighted public participation

11 Dr J. Sulianti Saroso was a much more recent graduate than other leaders of the time. She had graduated from GHS in 1942 and was awarded a wHO fellowship to study public health and mother and child health in Europe and the UsA in 1949. After fulfilling several important public health positions in the Ministry in 1950s, she became Director General at the Ministry of Health after 1968 and played a leading part in building strong relationships with the wHO and developing the health centre concept (Apa \& siapa 1989:277-278). 
and consisted of both medical service in clinics and health education, hence combining curative and preventive medicine. The Bekasi Project also aimed to achieve the in-service education of public health field staff. Eight other rural areas were selected for the expansion of the project through the expedient of sending educated staff to work there. Unfortunately, the Bekasi Project has been poorly documented (Better health 1960; Depkes 1994:8-9; Antara 6-8-1957).

Although the emphasis in each project was different -the latter two tended to focus more on public health education-, all of these projects were initiated by doctors with public health experience. Considering the fact that all these rural health projects were in areas relatively near to and accessible from cities and controlled by doctors based in the cities, the ideal of national standardization of health-care service in these cases meant the integration of the rural into the urban areas and not the distribution of medical services to outlying rural areas. At the same time, several mass preventive measurements against certain diseases, especially malaria and yaws, were launched, the majority of them in rural areas. These preventive rural campaigns required the presence of doctors for supervision and administration. Obviously, all these ambitious projects required more doctors if the project were to be expanded throughout the entire nation.

Unfortunately, in reality these plans were simply too ambitious to be realized for the whole nation. Exactly at the time when more doctors were needed to implement the new state ideals of rural health care, the number of doctors began to decline. Most of the Dutch or other European doctors went back to their home countries. The leading administrative and academic positions that fell vacant were filled by indigenous doctors, who consequently also gave up practice. Some of the indigenous doctors who had fought in the struggle for independence continued their career in the military and another group of doctors went into politics, both at the local and national levels. After the long period of turmoil of the Second World War and Indonesian Revolution there were fewer government doctors based in rural areas than there had been in colonial times. It is hard to obtain exact data for the whole nation at that time, but the Province Series published by the Ministry of Information provide information on several provinces. Although the reliability of the data is questionable and the method of categorizing in each province obscure, the Province Series does give the impression that the alteration in the number of doctors was spread unevenly and services with the exception of those in Jakarta and a few provinces in the Outer Islands were decreasing (Kementerian Penerangan 1953).

In short, the pursuit of rural health was thought to be the task of the state; more than an end in itself, it presented a way to legitimize the national 
leadership. The goal of the pursuit of rural health required the standardization of medical provision throughout the country. Although national health-care leaders did not explicitly promote Western medicine, as colonial opinion leaders like De Vogel had done, they never contemplated indigenous or local medical practice as a frame of reference. The contents of their projects and the existence of international support reveal the continuance of the domination of modern medicine (or biomedicine), which is predicated on science, in this pursuit of rural health. The ambition to achieve rural health by Western standards was overwhelmingly great, but it was difficult to attain this goal with the limited number of trained personnel the state then had at its disposal.

\section{Simple Solutions for Overwhelmingly Complex Problems}

To solve the discrepancy between the government ambitions and the disappointing reality, national leaders realized the time had come to exercise more control over their medical personnel. Consequently, three laws were passed to regulate a more rational distribution of health-care specialists. These laws were the first laws issued by the Ministry of Health. In this section, I shall begin by describing the content of the laws and the legislative process, arguing that the complexity of the demand at the local level was actually accorded scant consideration in the legislative process. The preference was given to 'national needs' and the discussion concentrated on the professional liberty of the specialists to set up practice where they wished.

Ever since the end of the colonial era, the task of assigning doctors had been in the hands of the central government. In 1940, out of 703 governmentemployed doctors only eighty-nine were employed by local governments (Indisch Verslag 1941, II:78-79). Hampered by the lack of doctors outside the major urban centres in Java, local governments repeatedly requested the central government for the placement of more doctors in their respective regions. Juggling with this problem, the Law to Give Authority to the Government for Distributing Doctors according to the Interests of the State (kepentingan Negara) had begun to be discussed even before the unitary state came into being (Antara 25-7-1950).

In June 1951, the government passed three acts. The first, Law 8/1951, required newly qualified doctors and dentists to work for the government for three years before being granted permission to set up as an independent practitioner. The second, Law $9 / 1951$, prohibited the opening of new medical practices by doctors, dentists, and midwives in areas declared closed by the Minister of Health. The third, Law 10/1951, gave the government the authority to 
requisition the services of private doctors temporarily in such 'times of crisis' (keadaanjang genting) as natural disasters, epidemics and other major calamities (Lembaran Negara 1951, No. 44, 45, 46). Law 9/1951 was implemented by the Ministerial Decision of 15 August 1951, prohibiting the opening of new medical practices in a number of the most important urban centres: Jakarta, Bandung, Semarang, Surabaya, Medan, and Malang; subsequently Makassar was declared closed in October 1951, Palembang in December 1954, and finally Tanjung Karang and Pangkalpinang in January $1955 \cdot{ }^{12}$

It would be interesting to know why the Ministry decided these bills were necessary and on what grounds the said cities were declared closed to new practitioners. Unfortunately, no records of the internal discussions in the Ministry of Health have survived in the archives of the Ministry. Nevertheless, the discussion in Parliament does give some insight into the argumentation used to support the bills. The Ministry of Health presented each of the three bills first to a Committee from the national Parliament (Panitia Permusyawaratan), then to an Ad Hoc Committee (Panitia ad hoc), set up to discuss the bills for four days, and only then to the Plenary Session (Rapat Pleno) of the Parliament. No records have survived of the proceedings in either committee, but the minutes of the Plenary Session, of 20-21 June 1951, still exist. The following analysis of the argumentation of the Ministry is based on proceedings of that Plenary Session. ${ }^{13}$

In response to the questions posed earlier by the Ad Hoc Committee, Minister of Health Leimena explained that these drafts were based on the ideals embodied in Article 42 of the Provisional Constitution of the Republic of Indonesia of 1950, which stated that the government should never cease to make a sincere effort to improve overall hygiene and public health. The Committee had asked for clarification about what criteria the government used to decide that a serious shortage of medical specialists existed in a region or, conversely, decided that a certain city had enough specialists. The Minister only answered that his choice of certain regions expressed the 'reality' of the local needs without giving particular numbers or other hard criteria from which to evaluate the demand at the local level.

The discussion in the Plenary Session showed the Parliament was basically prepared to go along with the government plans. The main point of discussion

12 Soerat Kepoetoesan Menteri Kesehatan No. 23398/UU 15-8-1951, No. 32810/UU 18-10-1951, No. 90112/Kab 16-12-1954, No. 3062/Kab 13-1-1955 (Berita Kementerian Kesehatan August 1955, March 1956).

13 Perpustakaan Dewan Perwakilan Rakjat, Jakarta (Perpustakaan DPR), Risalah Dewan Perwakilan Rakjat 1951: Rapat 88 (20-6-1951) and 89 (21-6-1951), pp. 5183-5254. 
was the question of whether it was fair that only newly graduated medical personnel be obliged to work for government, and that only medical specialists, and not other specialists such as lawyers, were required to fulfil this obligation, which restricted their professional liberty to exercise their specialty. The Minister did not give an unambiguously satisfactory explanation of the first point, merely considering it a psychological problem for the new graduates, which was less important than the 'real' needs. On the second point of friction, the Minister said that a basic law on the utilization of specialists (doctors, lawyers, teachers and so on) was being considered by other ministries. If such a basic law expressed the same idea as that in his bill, Minister Leimena argued a generic law for all specialists presented no problem but it would take five to ten years for it to reach the stage of legislation. Pending such a law for all specialists, it was better to pass these bills of the Ministry of Health first and make doctors 'pioneers' (pelopor). The term pelopor was coloured by its meaning derived from the vanguard of freedom fighters during the Indonesian Revolution; this positive connotation cannot have eluded the members of Parliament less than two years after the revolution. Finally, Leimena made a vaguely worded emotional appeal reminding his audience of the difficulties experienced by people far from cities and followed this by an evocation of the 'spirit of Independence Day' (semangat dari 17 Agustus 1945). On the second day of the discussion, these three bills were passed with the general consent of the members of Parliament.

The public reaction did not diverge greatly from the tenor of the parliamentary discussion. It seems that only those medical specialists mentioned in the laws were seen to be the interested parties. Only these specialists personally and their professional associations had previously been consulted. University students from the Faculties of Medicine in Jakarta and Surabaya sent the government the resolutions of a students' meeting, which rejected the draft. They argued that restrictions placed only on newly graduated specialists and on new practices were not the right way to tackle the problems, because the former did not really solve the present shortage of specialists and the latter would protect vested interests. Nevertheless, they did basically agree on the need of a rational geographical distribution of specialists and requested the government consult more representative groups, not just the Ikatan Dokter Indonesia (IDI, Association of Indonesian Physicians). ${ }^{14}$ As had been the case with the

14 ANRI, Kabinet Presiden RI 633, letter Mahasiswa Fakultas Kedokteran Jakarta dan Surabaya kepada Presiden RI, surat pernyataan tanggal 17, 21-4-1951 tentang tuntutan supaya RUU pembagian tenaga-tenaga ahli kesehatan secara rasional ditinjau kembali; Antara 17-4-1951. 
questions asked in Parliament, this request does not seem to have been considered grounds for making a policy change by the government.

It is difficult to say whether there was any reaction from the public over and above this or to discover how other specialist organizations reacted. Apart from the materials I obtained from newspapers and archives of requests, there seems to have been no reaction. Moreover, it appears that these laws were not widely disseminated through any concerted public information campaign. In the more than fifteen newspapers and Antara News Agency Report of the 1950s I checked, I came across only three reports that the bill had been passed. ${ }^{15}$ Moreover, I found only three newspaper reports, sometimes just in passing, about the closure of a city to new medical practices (Antara 15-8-1951; Merdeka 21-8-1951; Pemandangan 22-8-1951). All of these were news items pure and simple and there were no opinions or reactions reported.

Even though these laws authorized the government to utilize newly graduated doctors and to close several big cities to doctors who wished to establish a new practice so as to ensure an equal distribution of doctors throughout the country, their impact on the actual situation was minimal. At the moment at which it was passed, Law 9/1951 already contained a loophole: governmentemployed doctors were allowed to open a private practice to supplement their income. Hence, whenever government posts were expanded, a new opportunity to set up a new private practice opened up as well. In fact, in the $1950 \mathrm{os}$ there were many government projects to build new hospitals and to open new faculties of medicine or research institutes, which necessitated just such an expansion of posts. These activities were especially prevalent in provincial capitals, that is, precisely those cities closed to new practices. Furthermore, in response to a 1953 resolution by the Ikatan Dokter Indonesia, the exception was extended to retired government doctors who had worked for the government for more than fifteen years and had been granted an honourable discharge (Antara 2-5-1953).

15 Antara 21-6-1951; Harian Umum 25-6-1951; Pemandangan 2-8-1951. Besides the Antara News Agency Reports (Antara), the following newspapers were checked: Berita Indonesia (Jakarta), Fikiran Rakjat (Palembang), Harian Indonesia (Bandung), Harian Penerangan (Padang), Harian Umum (Surabaya), Indonesia Berjuang (Bandjarmasin), Kedauratan Rakyat (Yogyakarta), Malang Post (Malang), Merdeka (Jakarta), Pedoman Rakjat (Makassar), Pemandangan (Jakarta), Soeara Rakjat Sumatera (Palembang), Suara Merdeka (Semarang), Trompet Masjarakat (Surabaya), Waspada (Medan). I was helped by Irwan Yudhi from Universitas Indonesia, Ida Liana Tandjung and Budi Kristanto from Universitas Gadjah Mada. I would like to convey my sincere appreciation to them. 
Besides the loopholes in the laws, there was a second reason the laws intended to distribute doctors more evenly proved difficult to implement: the number of doctors who graduated each year was quite small in the 1950s. One professor reported that only three students from among 57 candidates actually sat their final examinations at the Faculty of Medicine in Surabaya and even the older medical faculty in Jakarta produced only 30 graduates per year at most (Harian Umum 7-2-1952). It was also reported that only 84 doctors were produced in the four-year period 1950-1953, just at a time most of government doctors were approaching retirement age (Harian Umum 7-12-1953). Even if most of the new graduates had been posted to rural regencies or had filled the vacancies caused by retirement, these were far from enough, as the students had anticipated in their above-mentioned resolution of 1951.

I have not found exact numbers to show the distribution of doctors for the whole of Indonesia in government materials from the 1950s. However, newspapers often reported that local governments, local parliament members, or nongovernmental organizations had demanded more medical personnel or facilities and had complained about a lack of health specialists. Between December 1953 and August 1957, 27 requests for health specialists and medical facilities from local mass organizations were forwarded. ${ }^{16}$ So, in spite of the insistence of the national government that it fostered 'good health for the whole society' in contrast to its colonial predecessor, in reality people in some places complained there were fewer facilities and fewer medical staff than in the colonial period.

Some cases reveal the diversity and complexity of the problem well. In 1951, according to the Head of the Health Service of Malang, there were 47 doctors, both government and private, in the Residency of Malang, which came down to one doctor to 66,00o people. Of these 47 doctors, only three worked in the regentschap (district) of Malang, the rural area; in other words there was just one doctor to 400,000 people. Nevertheless, it was still thought that, compared to other rural areas, relatively speaking the regentschap had enough doctors. Before the war there had still been five doctors in the regentschap, two more than in 1951, and the newspaper concluded that now most doctors generally lived in town (Malang Post 16-7-1951, 3-8-1951).

16 ANRI, Kabinet Presiden RI 656, Organisasi-organisasi massa, resolusi-resolusi 22-12-195315-8-1957 tentang tuntutan kepada pemerintah untuk menambah tenaga-tenaga ahli kesehatan ke pelosok-pelosok desa; Kabinet Presiden RI 659, Organisasi-organisasi massa, resolusi-resolusi 16-8-1954-16-10-1954 tentang tuntutan jaminan kesehatan dan fasilitasfasilitas kesehatan. 
Another case, from the Kahayan Hulu District, South Kalimantan, was reported in Indonesia Berjoeang in 1954. The district consisted of three subdistricts and 110 villages (kampong) with a total population of 30,000 people, mostly Dayak, situated in the inland from where it was difficult to reach the city of Banjarmasin, at least by land transport. In 1934 the population requested the regional government (the Resident in Banjarmasin) to station a doctor (tabib) in the interior and the next year, in 1935, the request was granted. Then, with the profits they had obtained from rubber, the population built hospitals and a doctor's residence. Subsequently, the upheaval caused by the Japanese occupation affected medical care, but another doctor did sustain medical care in the area. After Independence, when this other doctor opted to go into politics and moved to Banjarmasin, the area was consequently bereft of any physician. For years no heed (perhatian) was paid to people's requests for doctors (Indonesia Berjoeang 3-8-1954).

Trompet Masyarakat (31-10-1955) reported the shortage in Blitar, East Java, in 1955. There had been five doctors in the colonial era, but now there were only two. The mayor said that the government's efforts had failed to bear fruit because doctors did not want to open a practice there. He explained that, unlike the situation in colonial times when many Dutch people worked for plantations or sugar factories, Blitar was now considered a less profitable place than other big cities.

The final example is the Organisasi Patien Pejakit Paru-paru (Organization of Lung Disease Patients) at the Hospital in Pematang Siantar, North Sumatra. This organization requested the President, Minister of Health and other authorities to station doctors specializing in lung diseases there, as from before the war up to 1956 there had been only one or two lung specialists. ${ }^{17}$

These four cases show the complexity of the demand on the ground, which was ignored by the promoters of 'rural health' in the national capital. Some rural societies lost their access to modern medicine, which in colonial times had been possible on the plantations (in Blitar) or in areas of smallholder export agriculture (in Kahayan Hulu). At some places, Pematang Siantar, for example, even specialist care had been provided to local population in colonial times and had since disappeared or diminished. The economic changes which accompanied the political decolonization and the other physical disturbances in the turbulent 1940s affected people in rural areas negatively. The national leaders, who discussed the matter collectively and simply, ignored the

17 ANRI, Kabinet Presiden 656, letter Penderita-penjakit Paru-Paru rsu Pematang Siantar to Presiden, Menkes, RSU Pematang Siantar, DPR Kabupaten Simelangun, DPR Kotapradja Siantar, 30-4-1957. 
difference in impact from place to place. Nor was this the only fly in the ointment. Local variations in medical care were also the outcome of another factor. When the central government considered the question of where to place medical personnel, it demanded the local government or the community supplement the fringe benefits, especially housing. Inexorably, the financial condition of local governments, which differed greatly from each other, mattered. In some cases plans to post a doctor were cancelled because it was impossible for the local government to provide housing (Antara 17-10-1952; Pikiran Rakjat 13-11953; Harian Umum 24-6-1953).

As a consequence, feelings ran high as it was believed that doctors or other health specialists were still concentrated in an urban setting, perhaps even more than before (Malang Post 16-7-1951, 3-8-1951; Pemandangan 6-5-1954; Pikiran Rakjat 2-6-1956). As these cases show, the shortage in medical provision was felt more by those people who had already enjoyed its benefits in colonial times. The situation was made even more complicated because to boost national pride and to meet the need for premier medical care, more modern facilities were needed in administrative centres. Those places already touched by modernity refused to relinquish these facilities. How little changed in the 1950s becomes apparent from the national distribution of doctors recorded around 1964 (Table 2.2)..$^{18}$ Despite all the efforts made by the government, provincial capitals and other big cities received the lion's share of the allocation of medical staff, and rural areas were hard done by. Indeed eleven districts were still completely without doctors. ${ }^{19}$

In a nutshell, the newly independent Indonesian government gained formal state control over the distribution of medical personnel by law. The legislation process focused on the sole issue of whether doctors had the professional liberty to settle where they pleased; this professional liberty was challenged by full government control. The state control was legitimized by an appeal to 'national idealism'. The upshot of this scrambled situation was that the state control of the distribution of medical personnel failed to achieve the ideal of

18 The list named Daftar nama dokter-dokter Dep. Kesehatan dan penempatannja, found in the library of the Departemen Kesehatan, does not give the year in which the list was compiled. As it includes doctors of 'Dwikora', a slogan meaning the Confrontation with Malaysia after 1963, and as Sulawesi was already divided into four provinces, I assume this list was compiled around 1964. Dwikora doctors were included among those who were waiting for placement.

19 I counted the number of districts (kabupaten) on the list without the names of doctors. There is a possibility that districts that had never been allocated a doctor were not included on the list. Another source comments that there were thirty-three regencies without doctors even as late as 1969 (Sumbung 1972:58). 
TABLE 2.2 Distribution of doctors by province around 1964

\begin{tabular}{|c|c|c|c|}
\hline Province & $\begin{array}{l}\text { Number of } \\
\text { government } \\
\text { doctors }\end{array}$ & $\begin{array}{l}\text { Doctors in provincial } \\
\text { capitals and other cities }\end{array}$ & $\begin{array}{l}\text { Districts without a } \\
\text { doctor }\end{array}$ \\
\hline Atjeh & 32 & Banda Atjeh 3 & \\
\hline Sumatera Utara & $5^{1}$ & Medan 31 & \\
\hline Sumatera Barat & 15 & Padang 13 & Pesisir Selatan \\
\hline Djambi & 10 & Kota Djambi 9 & \\
\hline Riau & 13 & Pekanbaru 11 & \\
\hline Sumatera Selatan & 78 & Palembang 34 & Muara Enim \\
\hline Lampung & 17 & Tandjung Karang 12 & \\
\hline Djakarta Raya & $395^{*}$ & & \\
\hline Djawa Barat & 99 & Bandung 56; Bogor 10 & \\
\hline Djawa Tengah & $15^{8}$ & $\begin{array}{l}\text { Semarang } 74 \\
\text { Surakarta } 31\end{array}$ & Bandjanegara \\
\hline Djogjakarta & 30 & Kota Djogja 24 & \\
\hline Djawa Timur & 199 & $\begin{array}{l}\text { Surabaja 94; Kota } \\
\text { Malang } 35\end{array}$ & Bangkalan \\
\hline Kalimantan Barat & 19 & Pontianak 11 & Sintang \\
\hline Kalimantan Tengah & 2 & & Kuala Kapuas \\
\hline Kalimantan Selatan & 12 & Bandjarmasin 12 & \\
\hline Kalimantan Timur & 17 & Samarinda 7 & \\
\hline Sulawesi Utara & 29 & Manado 11 & \\
\hline Sulawesi Tengah & 4 & & Poso \\
\hline Sulawesi Tenggara & 3 & & Koleka, Muna \\
\hline Sulawesi Selatan & 31 & Makassar 30 & Bonthain \\
\hline Maluku & 13 & Ambon 12 & \\
\hline Nusa Tenggara Barat & 30 & Den Pasar 14 & \\
\hline Nusa Tenggara Timur & 9 & Kupang 8 & $\begin{array}{l}\text { Timor Tengah } \\
\text { Selatan }\end{array}$ \\
\hline Irian Barat & 45 & & \\
\hline Indonesia & 916 & & 11 districts \\
\hline
\end{tabular}

*Another 272 doctors were waiting for placement. SOURCE: DAFTAR NAMA (1964). 
'rural health'. This failure was caused partly by the insistent call for (more) modernity in the major urban centres, which overrode and undermined the call for equality. Another cause, which contributed to the failure, was that the prescription demanding the even distribution of doctors was too simplistic in the face of the overwhelmingly complex reality. After all, the really alarming dearth of qualified personnel had to be solved if national leaders meant to achieve both modernity and equality. ${ }^{20}$

\section{Seeking Other Solutions for the Shortage of Medical Personnel}

If the problem really could be reduced to the shortage in medical personnel, the solution was obvious: the government should increase their number. In this section, I show how the government did indeed try to increase the numbers of personnel and on which groups of personnel it focused.

In some countries, especially in the early stages of state building, priority is given to quantity. Quality has often been allowed to go by the board. This is done by enlarging the scope for gaining qualifications by the expedient of simplifying the training, by including traditional providers or by institutionalizing auxiliary personnel. For instance, the government of Japan allowed traditional medical providers to obtain modern medical qualifications by simplifying the examinations to allow them to practise at the end of nineteenth century (Hashimoto 2003:117-120). In China, 'bare foot doctors' at the commune level enjoyed great fame in the 196os and a similar system also existed in Vietnam (Purcal 1989; Beresford 1995).

Interestingly enough, despite the enormous dearth of qualified medical personnel, the Indonesian government did not choose to adopt such methods. One reason was that the national leaders in the health sector, who consisted mostly of doctors, absolutely refused to acknowledge other auxiliary personnel as legitimate medical providers. As I have said, the mantri were categorized as nurses who had no legal right to practise medicine independently, a restriction which had been carried over from the colonial period. In 1952, the Minister of Health, Dr Leimena, issued an announcement (maklumat) stipulating that medical practice was unconditionally a job for doctors whose professional position was protected by law. Nevertheless, it was possible to take some judicious measures (tindakan bidjaksana) on private medical practice provided by

20 Also compared to the neighbouring former colonies, the number fell far short. Moreover, Antara reported that, according to the UN Statistical Yearbook, the Indonesian ratio of doctors to people, 1 to 71,00o, was lower than in African countries (Antara 15-4-1957). 
nurses, whose speciality was to care. He showed compassion for the economic difficulties suffered by nurses at the time, but stated in unequivocal terms that medical practice was the exclusive right of doctors. Doctors had followed a specialized educational training, and nurses or mantri should only be allowed to practise under a doctor's supervision. One reason the Ministry found it difficult to pass on more responsibilities to mantri was the fact that auxiliary personnel were educated in local hospitals, and their training was not supervised by the central government. ${ }^{21}$

When this proclamation was reported in newspapers and on radio, the Persatuan Djuru Kesehatan Indonesisa (PD KI, Indonesian Nurses' Association) reacted strongly. They perceived it as an insult and accused the government of unfairness in allowing government doctors to pursue private practice in office hours. The Minister hastened to make his excuses and to insist he had intended no offence. He was forced to apologize both publicly and in Parliament (Antara 7-2-1952, 20-2-1952, 21-2-1952; Harian Umum 25-6-1952). Even after this incident, the government continued to rely on the medical expertise of nurses or mantri to supplement local needs (Antara 15-2-1955). The point was that national leaders needed the nurses, but could admit them only in governmental institutions, as the leaders wished to protect the doctors' market. The upshot was that neither the role nor the presence of nurses working as medical providers was to be either admitted or discussed publicly.22

If nurses were banned from acting as formal medical providers, were any other categories created for auxiliary medical providers on a local basis? This never seems to have been discussed. The Japanese occupation authorities did establish a school for auxiliary doctors (Hodjoi Gakko) and a (medical) technical college (Senmon Gaku) in Semarang to educate nurses and junior high school graduates for each role in 1944, but these two schools were closed at the end of Japanese occupation (Panitya Peringatan 1976:128). ${ }^{23}$ After the closing of the two Japanese schools, no such schools or plans were ever heard of again.

Only the school for assistant pharmacists, which was also founded in the Japanese period, raised some discussion in the 1950s. As there was no school for pharmacists in the Netherlands Indies, qualified pharmacists were also few and far between after Independence. In 1953, assistant pharmacists or assistants apprenticed to certified pharmacies were allowed to head a pharmacy

21 ANRI, Kabinet Presiden RI 641, Menteri kesehatan, Maklumat II 19-1-1952 tentang praktek dokter oleh mereka yang tidak berhak (onbevoegd).

22 This ambivalence has continued to the present time (Sciortino 1995).

23 I have not obtained any further information on these schools so far. On the strength of its name, it is even unclear if the latter was expected to educate medical personnel. 
independently for five years under the Law 4/1953 on emergency pharmacies and the schools to train assistant pharmacists were expanded. In 1959, after due consideration of the still unsettled situation, this law was extended for another five years. At this point in time, Indonesia had about 200 qualified pharmacists and 2,000 assistant pharmacists. To give these assistant pharmacists a chance to become qualified pharmacists, Faculties of Pharmacy opened special courses in which they could continue their studies. These special courses were seen as a transitional measure. ${ }^{24}$ I refrain from going into this discussion or the problems encountered in pharmacies, but this measure to establish proper courses for auxiliary personnel and to up-grade them in a time of transition would have seemed more rational had the government really meant to train and distribute enough medical personnel. In reality the measures were only applied to doctors.

Two government measures to solve the shortage of doctors were of some importance. The first of these was to employ doctors from overseas. Just after the transfer of sovereignty, the Indonesian government commenced recruiting doctors on a three-year contract basis (Antara 3-11-1950). Foreign doctors began to come in $195^{2}$ and at one point more than 300 foreign doctors were working for the government (Antara 12-3-1952, 5-2-1955). It is unclear when and how this policy was discontinued. Most of the contracted doctors seemed to have returned to their homelands after their three years had elapsed. It is highly likely the scheme stopped around 1957 when nationalistic sentiment increased and simultaneously the number of Indonesian medical graduates began to rise.

The policy of contracting foreigners was not always welcomed by society. The Ikatan Dokter Indonesia (IDI, Association of Indonesian Physicians) stated that the salary of foreigners should not be much higher than that of indigenous doctors and repeatedly expressed their discontent with the difference in treatment (Pemandangan 10-12-1952; Merdeka 8-12-1953; Antara 18-11954). In some places minor health staff went on strike or submitted petitions objecting to the policy or attitude of the imported doctors to them (Pikiran Rakjat 29-9-1953; Antara 5-5-1955, 11-6-1955). Generally speaking, however, the need for these foreigners weighed more heavily than the problems they created and there were never any drastic alterations in the policy to attract foreigners before it silently petered out. It was not so much the objections of Indonesian medical staff, but other factors which ultimately ended the recruitment of foreign doctors. Bringing in doctors was not cheap and their quality

24 Perpustakaan DPR, Risalah Dewan Perwakilan Rakjat 1959, Masa Persidangan II, Rapat 57 (27-5-1959), Rapat 58 (29-5-1959) and Rapat 59 (1-6-1959), without pages. 
was not always guaranteed, because the doctors were not selected but had applied personally. Moreover, in due course it had become more and more difficult to obtain foreign doctors (Antara 25-10-1956).

The second solution to the shortage of doctors was to improve the efficiency of medical training in Indonesia and to raise the standard of graduates from Indonesian medical faculties. As mentioned above, the numbers of doctors produced per year were very small in the early 1950s. Although the number of medical faculties had increased from three in 1950 to twelve in 1963, this growth did not portend a quick end to the shortage of doctors, since it took time for qualified graduates to come through (Panitya Peringatan 1976:130-131). Consequently, from a very early stage, there were calls for the reform of medical education (Harian Umum 7-2-1952). The Ikatan Dokter Indonesia made resolutions to augment the quality of the medical training in both $195^{2}$ and 1953 (Pemandangan 20-12-1952; Harian Umum 7-12-1953). However, as the education of doctors was the responsibility of the Ministry of Education and Culture, the Ministry of Health could not change the curriculum.

A major change was initiated in the educational programme for quite another reason. The Universitas Indonesia (UI, University of Indonesia) decided it had to increase the numbers of its own lecturers, in particular as Dutch lecturers had begun to leave Indonesia just as student numbers were rising. After a few twists and turns, an 'affiliation' programme with the University of California was commenced informally in $195^{2}$ and was made official in 1954. To hammer out the new system, in 1954 the Faculty initiated a Panitia Kurikulum (Curriculum Committee) to change the system (Tjokronegoro 1956; FKUI 1960a:16-17). The biggest change introduced was that the length of the education was shortened from seven to six years. The programme was shortened by abolishing what was known as the free system (sistim bebas), inherited from Dutch times. Under the free system, students had been free to choose their own time of examination without any time limitation but, under the influence of American ideas, the free system was thought to be ineffective and promoting delays. In response, the Universitas Indonesia introduced a system of structural courses with a fixed schedule of examinations, which was called guided study (studi terpimpin) (FKUI 196ob; Pemandangan 6-4-1957; Antara 6-11-1958). ${ }^{25}$ Under the new scheme, in 1959 the

25 Another result of this co-operation was that 112 staff members of the Universitas Indonesia were given the chance to study and be trained as lecturers in the USA, for a period of between three weeks to twelve months. Moreover, 38 American staff members from the University of California, including administrative personnel, spent a period of six years in Indonesia (FKUI 196ob). The languages of instruction were both Indonesian 
Universitas Indonesia could produce 158 doctors, of whom 98 had passed through the new system. A university spokesperson declared it was possible to produce more than 150 doctors a year 'without lowering the quality'. ${ }^{26}$

It was not just the programme, which was altered; the relationship between students and professors changed drastically. One of the last graduates from the old system told me that in the Dutch system students could be arbitrarily disqualified by a professor as professors were 'like God', but in the American system students and professors were 'in one community' and any students' failure was attributed to the professors' inability to teach properly. Although some students expressed dissatisfaction stating that the new system had increased the burden on students, on the whole it was seen as a success and it was gradually extended to other universities (Pikiran Rakjat 5-4-1958; Tumbelaka and Mardjono 1976:70).

Worthwhile though they may have been, these government efforts were as yet insufficient to satisfy the demand for new doctors and also failed to meet the ambitious plans. Even though the shortening of medical education from seven to six years bore fruit in the long run, much water had to flow under the bridge before the structure was changed drastically; Indonesia did not begin to benefit fully from the growing number of doctors until the $1970{ }^{27}{ }^{27}$ In the 1950s, the Indonesian government still seemed to be lacking in initiative or perhaps was unwilling to make structural changes.

\section{The Popular Demand for Doctors: Ambivalent Consequences}

How did society respond to the shortage of doctors? Remarkably, apart from the already mentioned 'requests' and 'resolutions' to increase medical provision in certain regions, little discontent about the inability of the state to do something about the medical services was voiced..$^{28}$ It was the doctors, rather

and English. Indonesian had begun to be the medium of instruction in the Japanese occupation period. It is unclear whether the government or an assistant agency funded the translation of textbooks, but books were contributed in this scheme. The idea that more guidance was necessary as a means to restrict too much freedom was, of course, also introduced into the political system with the term Guided Democracy (Demokrasi Terpimpin) in the late 1950 .

26 Antara 10-8-1959; FKUI 196oa:88; interview with Dr Soebekti 13-7-2004.

27 Interview with Dr Soebekti 29-3-2004, 30-7-2004.

28 I have obtained only scant information about how political parties made decisions at the national level (but some of the local requests for doctors submitted to the central government were the work of local branches of a political party). The only case I found of a 
than the government, who found themselves the target of public criticism and complaints. Subsequently, these critical public voices were picked up by doctors themselves or by government leaders urging the doctors to shoulder their 'moral obligation', echoing the call for doctors to become pioneers (pelopor) voiced by Leimena in 1951 .

The first moral appeal to doctors was made in Surabaya in 1951. Several local newspapers criticized doctors of Chinese descent for allegedly often not answering a house call for a doctor. ${ }^{29}$ Although the root problem was the dearth of doctors itself, and indeed doctors were sometimes right in ignoring a call, as there was no urgency, these Chinese doctors began to organize a rota shift to cover the night hours (Harian Umum 20-10-1951). When the criticism began to heat up again despite the initiative of launching a rota shift, the Surabaya branch of Ikatan Dokter Indonesia also felt impelled to take action. The association sent questionnaires to 130 doctors in Surabaya, of whom about 80 practised privately, asking about their readiness to be on call at night and on holidays. Among the 35 private doctors who responded, only five declared they were willing to work night hours and 27 were prepared to be on call on holidays, but under several specific conditions (Antara 13-12-1951, 6-1-1952).

Another moral call to doctors was made in South Sulawesi. When the provision of medical services in South Sulawesi grew precarious, the Minister of Health, Dr M. Ali (Lie Kiat Teng), appealed to private doctors' 'moral obligation' to work there voluntarily, and referred to the possibility that Law 10/1951 might be invoked to force them to do so (Antara 16-1-1954; Harian Umum 17-11954). ${ }^{30}$ Confronted by the Ikatan Dokter Indonesia, which construed the

political party, which did discuss the position of doctors at the national level, was the Partai Kebangsaan Indonesia (PARKI, the Indonesian Nationalist Party). The Partai Kebangsaan Indonesia demanded the government socialize health care (sosialisasi kesehatan) by making all doctors state-employed (Harian Umum 17-4-1952).

29 A disproportionate number of doctors had a Chinese background. Students of Chinese descent had been entitled to enrol in medical schools since the colonial period. In 1943 the Japanese authorities counted 163 doctors of Chinese descent out of 648 doctors in Java (Jawa Shinbunsha 1944:158). The 1964 list reveals that almost half the doctors on the list had a Chinese name (Daftar nama 1964).

$30 \quad$ Dr M. Ali or Lie Kiat Teng served as Minister of Health from October 1953 to August 1955 in the cabinet of Ali Sastroamidjojo and Wongsonegoro as a politician from the Partai Sarekat Islam Indonesia (PSII, Indonesian Islamic Union Party). As Minister he installed the Madjelis Pertimbangan Kesehatan dan Sjara (MPKs, Council for Consideration of Health and Islamic Law) and reminded doctors of their moral obligations. His ambivalent personal position as a Chinese Muslim politician is a possible explanation of his strong 
reference to Law 10/1951 as a threat, Ali explained that the health of a nation of 80 million had to be the priority of the doctors (Harian Umum 21-1-1954). Moreover, at a meeting with the Semarang Branch of Ikatan Dokter Indonesia, Ali stated: 'In some places the people themselves were threatening and harassing private doctors, fed up with suffering from the dearth in medical provision'. Ali continued by asking the Ikatan Dokter Indonesia representatives:

Can I say to the people that private doctors, especially those of nonindigenous descent, sincerely feel they are 'citizens' [warga negara] of the Unitary Republic Indonesia and feel that Indonesia is their mother country [tanah airnja]?31

Merdeka 22-1-1954

This crisis in South Sulawesi seems to have been solved with the voluntary help of private doctors in South Sulawesi itself (Merdeka 16-2-1954). However, similar appeals to a 'moral obligation' continued and swelled to a larger proportion in the middle of the 1950s.

Yet more moral appeals were made to doctors. The mayor of Jakarta gathered private doctors in his office to ask them to work part-time for the government clinics to cover the lack of government doctors and only two doctors from around the 150 doctors present refused the request (Antara 21-10-1954). The Bandung Branch of Ikatan Dokter Indonesia, also spurred into action by the mayor, organized a rota shift for night and holiday hours (Antara 3-2-1955). Observing this rota shift, one of the readers of Pikiran Rakyat from Tasikmalaya complained about the 'inhumanity' of several doctors who had failed to respond to a call, when assistance for her child had urgently been needed; the child had died. She consequently urged the Ikatan Dokter Indonesia to supervise doctors more strictly (Pikiran Rakjat 30-6-1955). When similar complaints were made, some doctors tried to explain the situation from the doctor's point of view and appealed to the understanding and morality on the part of patient. Yet their voice was too subdued to impress the public. Dr Ali Akbar, a member of parliament and also a medical doctor, supported a proposal to set up some kind of agency to supervise doctors' morality. ${ }^{32}$ This proposal sparked off a

moral appeals. After his replacement, he was accused but later acquitted in a corruption scandal.

31 The term'warga negara' (state citizens) in the original was used only to refer to people whose loyalty was questioned, in particular the Chinese.

32 Dr Ali Akbar from West Sumatra was a prominent doctor from the Islamic community. After Independence he became ambassador to Saudi Arabia, 1950-1954, and then taught 
discussion between members of Parliament and Minister of Health Leimena after a child of one of the members of the parliament lost its life under similar circumstances to the child in Tasikmalaya. Leimena admitted that there were doctors who forgot the Hippocratic Oath, but also seized the opportunity to explain the difficulty in building up the number of doctors (Pikiran Rakjat 11-111955, 16-11-1955; Antara 21-11-1955, 24-11-1955).

The inability of the state to solve the dearth of medical personnel in the short run had been transformed into a questioning of the morality of individual doctors by both the government and the public at large. What interests me is that the popular demands or discontent never really developed into a strong surge of public opinion criticizing the state. Instead, the public 'complaints' assumed the guise of public backing for, hence legitimized, state intervention in the professional freedom of the small community of doctors. By the end of the period of Parliamentary Democracy, it was already difficult to raise objections to such state intervention in the doctors' freedom (as had been introduced by the legislation of 1951). The process of state intervention reached its apogee in the period of Guided Democracy with the passing of Law 9/1961 on the conscription of university graduates and the organization of 'volunteer' doctors of Trikora and Dwikora to be stationed in a war zone (Antara 26-1-1958; Depkes 1980:94). ${ }^{33}$ By that time Ikatan Dokter Indonesia, which had still threatened the government with a strike in 1954 when the Minister of Health had commenced appealing to moral obligations (Antara 18-1-1954; Harian Umum 22-1-1954), no longer raised a dissenting voice. Instead, Ikatan Dokter Indonesia co-operated with the government in formulating a moral code for doctors. ${ }^{34}$ This new strong, in a way arbitrary, control of health specialists was continued under the New Order. In conjunction with the steady rise in the number of doctors as a consequence of the reform of the curriculum of medical faculties described above, the firmer control gained over doctors finally enabled the state to achieve the ideal of having one doctor for 30,00o people at the sub-district level towards the end of the 1970s.

at several universities. As a member of the Masjumi political party, he became a member of parliament in 1955. He had already been working for the Ministry of Health since 1954 helping to organize the MPKS (Roeder 1971:20).

Trikora was a slogan to mobilize people to wrest New Guinea (Irian Jaya) from the Dutch. The Dewan Pelindung Susila Kedokteran (Council for the Protection of Medical Ethics) was established in 1959 by Ministerial Decision (Soerat Kepoetoesan Menteri Kesehatan No. 247090/UP/Kab 5-11-1959). The first ethical code was published by the Musawarah Kerdja Susila Kedokteran Nasional (Workshop on National Medical Ethics) in 1969 (IDI 1959; Musawarah Kerdja 1969). 


\section{Conclusion}

In this chapter I have examined the decolonization of one modern state function, medical provision, in the 1950s. In their efforts to distinguish themselves from their colonial predecessors, national leaders in the health sector did not reject modern Western medicine, but criticized its uneven distribution and insisted on filling the gap with the emphasis on rural health. The professed goal of spreading the benefits of national independence to the whole population necessitated the integration of rural health projects into national programmes, by way of the more standardized distribution of medical personnel throughout the country. This tendency espoused by national leaders is not surprising, given their educational background, international support, and not least the rapid development in modern medicine at that time.

Nevertheless, the historical progress depicted in this chapter reveals a more complicated picture of modernity. The first point to consider is that, taking account of the voices complaining about the loss of or deficiency in medical personnel in various places, the uneven distribution of medicine in the colonial period was not determined simply along racial lines or the urban-rural divide, as the national leaders had vaguely suggested. Actually, the distribution of medical provision was a patchwork experience of modernity, which was influenced by the modern sector economy. A more careful examination of the relationship between the economic conditions and the exact status of medical provision in each place before and after the war years will be a necessary step in future research.

The second point, which emerges, is that national leaders in the health sector, who took over the state health administration from their colonial predecessors, inherited the standard already set by the colonial experience. The discussion of the quality of medical education and the scant consideration given to the possible employment of other medical providers revealed a strong conviction in the importance of scientific expertise. Western medical science was at top of the hierarchy and should be used to fill the voids in medical provision in outlying areas of Indonesia. Whether this choice was right or wrong, this claimed universality of science restricted the workable arena for national leaders to (re-)establish the state function in their own way.

As a consequence, state control of the placement of medical personnel was the most important measure taken. Voices initially raised to defend professional liberty were quelled in the course of the 1950s. Gradually strong state control over medical personnel, especially doctors, was justified by reminding the doctors of their moral obligation toward their patients. This aspect of the doctors' calling was voiced by the population in the form of complaints, which 
were subsequently picked up by national leaders as a jumble in sore need of reorganization. The shared assumption that the state should assume responsibility in medical provision and that medical personnel should sacrifice themselves for the sake of the nation had prevailed. In sum, the state function as a provider of medicine had been strengthened by the complex experience of modernity in decolonizing Indonesia.

\section{References}

Apa \& siapa (1989). Apa \& siapa: Ilmuwan dan teknokrat Indonesia. Jakarta: Pustaka Kartini.

Astrohadikoesoemo, G. (1940). 'Sedikit pemandangan tentang obat-obat kita oentoek diselidiki', in: Het Tweede Congres van de Vereeniging van Indonesische Geneeskundigen, gehouden op 22, 23, 24 en 25 Maart 1940 te Soerakarta, pp. 200-201. [Soerakarta: Vereeniging van Indonesische Geneeskundigen.]

Balińska, Marta Aleksandra (1995). 'Assistance and not mere relief: The Epidemic Commission of the League of Nations, 1920-1923', in: Paul Weindling (ed.), International health organization movements, 1918-1939, pp. 81-108. Cambridge: Cambridge University Press.

Beresford, Melanie (1995). 'Health and development in Vietnam', in: Paul Cohen and John Purcal (eds), Health and development in Southeast Asia, pp. 104-19. Canberra: Australian Development Studies Network.

Better health (1960). Better health for rural Indonesia. [Djakarta]: Departemen Kesehatan Indonesia.

Boomgaard, Peter (1996). 'Dutch medicine in Asia, 1600-190o', in: David Arnold (ed.), Warm climates and Western medicine: The emergence of tropical medicine, 1500-19oo, pp. 42-64. Amsterdam: Rodopi.

Boomgaard, P. and A.J. Gooszen (1991). Changing economy in Indonesia: A selection of statistical source material from the early 19th century up to 1940, Vol. 11, Population trends 1795-1942. Amsterdam: Royal Tropical Institute.

Booth, Ann (1987). 'The colonial legacy and its impact on post-independence planning in India and Indonesia', in: Leonard Blussé, A. Booth and C. Fasseur (eds), India and Indonesia from the 1920s to the 1950s: The origins of planning, pp. 1-30. Leiden and New York: Brill. [Comparative history of India and Indonesia 1.]

Booth, Ann (1990). 'Nihon no keizai sinsyutsu to Olanda no taiou:Sykuminchi Indonesia no keizai seisaku', in: Sugiyama Shinya and Ian Brown (eds), Senkanki Tounan Ajia no keizaimasatsu: Nihon no nanshin to Ajia Oubei, pp. 199-230. Tokyo: Doubunkan.

Daftar nama (1964). 'Daftar nama dokter-dokter Dep. Kesehatan dan penempatannja'. [Unpublished document.] 
Depkes (Departemen Kesehatan Republik Indonesia) (1980). Sejarah kesehatan nasional Indonesia. Jilid II. Jakarta: Depkes.

Depkes (Departemen Kesehatan Republik Indonesia) (1994). Primary health care in Indonesia. Jakarta: Depkes.

Dubin, Martin David (1995). 'The League of Nations Health Organization', in: Paul Weindling (ed.), International health organization movements, 1918-1939, pp. 59-80. Cambridge: Cambridge University Press.

FKUI (Fakultas Kedokteran Universitas Indonesia) [1960a]. Laporan perkembangan pendidikan dokter pada Fakultas Kedokteran Universitas Indonesia Djakarta. [Djakarta: FKUI.]

F KUI (196ob). Lebih banjak dokter untuk Indonesia: Kisah bergambar daripada afiliasi antara Fakultas Kedokteran Universitas Indonesia di Djakarta dengan Universitas California di San Francisco, Amerika Serikat. [Djakarta: F KUI.]

Gunseikanbu (1944 [2604]). Orang Indonesia yang terkemuka di Djawa. [Djakarta: Gunseikanbu.]

Handelingen Volksraad (1921). Handelingen van den Volksraad. Batavia: Volksraad van Nederlandsch-Indië.

Hashimoto, Koichi (2003). "Ishi no "ryou" to "shitsu" wo meguru seijikatei: Kindai Nihon ni okeru ishi no senmonsyokuka', in: Morita Sachio and Tamura Eiko (eds), Shintai to iryo no kyouiku-syakaishi, pp. 115-35. Tokyo: Syowado.

Hitipeuw, Frans (1986). Dr Johannes Leimena: Karya dan pengabdiannya. Jakarta: Proyek Inventarisasi dan Dokumentasi Sejarah Nasional, Direktorat Sejarah dan Nilai Tradisional, Departemen Pendidikan dan Kebudayaan.

Huard, Pierre, Jean Bussy and Guy Mazars (1991). Asia no Igaku. Tokyo: Serika. [Originally published as Les médecines de l'Asie. Paris: Éditions du Seuil, 1978; translated and edited by A. Akamatsu, J. Takashima and Y. Hagimoto.]

Hydrick, J.L. (1937). Intensive rural hygiene work and public health education of the public health service. Batavia: [s.n.].

IDI (Ikatan Dokter Indonesia) (1959). 'Penetapan Dewan Pelindung Susila Kedokteran', Madjalah Kedokteran Indonesia 10-2.

Indisch Verslag (1931-1941). Indisch Verslag. I. Tekst van het verslag van bestuur en staat van Nederlandsche-Indië. II. Statistisch jaaroverzicht van Nederlandsch-Indië. 's-Gravenhage: Algemene Landsdrukkerij.

Jawa Shinbunsha (1944 [2604]). Jawa Nenkan: Syowa 19, Kigen 2604. [Djakarta]: Jawa Shinbunsha.

Kementerian Penerangan (1953). Republik Indonesia.Jakarta: Kementerian Penerangan. [Eleven vols.]

KoloniaalVerslag(1849-1930).KoloniaalVerslag.'s-Gravenhage:AlgemeneLandsdrukkerij. Leimena, Johannes (1953). Some aspects of health protection to local areas in Indonesia. [Djakarta]: Ministry of Health, Indonesia. 
Leimena, Johannes (1955a). Kesehatan rakjat di Indonesia: Pandangan dan planning. Djakarta: v/h G.C.T. van Dorp.

Leimena, Johannes (1955b). 'Rural health', Berita Kementerian Kesehatan 1 (Agustus):6-9. Lindblad, J. Thomas (2008). Bridges to new business: The economic decolonization of Indonesia. Leiden: KITLV Press. [Verhandelingen KITLV 245.]

LN HO (League of Nations, Health Organization) (1937). Intergovernmental Conference of Far Eastern Countries on Rural Hygiene: Report by the Preparatory Committee 3. Geneva: League of Nations, Health Organization.

Margoendiningrat, S. (1940). 'Ketabian didalam bangsa Indonesia di tanah Djawa', in: Tweede Congres van de Vereeniging van Indonesische Geneeskundigen, gehouden op 22, 23, 24 en 25 Maart 1940 te Soerakarta, pp. 222-234. [Soerakarta: Vereeniging van Indonesische Geneeskundigen.]

McVey, Ruth (1994). 'The case of the disappearing decade', in: David Bourchier and John Legge (eds), Democracy in Indonesia, 195 os and 199os, pp. 3-15. Clayton, Victoria: Centre of Southeast Asian Studies, Monash University.

Mochtar, R. (1938). 'Decentralisatie van den Dienst der Volksgezondheid', in: Het Eerste Congres van de Vereeniging van Indonesische Geneeskundigen gehouden op 24, 25 en 26 December 1938 te Semarang, pp. 43-55. [Semarang: Vereeniging van Indonesische Geneeskundigen.]

Mochtar, R. (1954). Usaha kesehatan rakjat dan pendidikan kesehatan rakjat di Indonesia. Jogjakarta: Jajasan Fonds Universiti Negeri Gadjah Mada.

Murakami, Saki (2003). 'Olanda ryou Higashi Indo ni okeru Hokenseido no Tenkai to Kindaikokka Keisei'. [MA thesis, Kyoto University, Kyoto.]

Musawarah Kerdja Susila Kedokteran Nasional (1969). Kode etik kedokteran Indonesia. Djakarta: [s.n.].

Panitya Peringatan (1976). 125th Pendidikan dokter di Indonesia, 1851-1976. Jakarta: Panitya Peringatan 125th Pendidikan Dokter di Indonesia.

Penris, P.W.L. (1949). 'Indonesia before the war: The part played by plantations in Java in the medical care of the population', Documenta Neerlandica et Indonesica de Morbis Tropicis 1:209-14.

Peverelli, P. (1938). 'Gemeentelijke individueele ziekenzorg', Locale Belangen 25(10): $3^{-14}$.

Pidato (1969). Pidato pada upatjan pemberian gelar Doctor Honoris Causa dalam Ilmu Kedokteran kepada Professor M. Soetopo. Soerabaja: Universitas Airlangga.

Purcal, John T. (1989). 'Development of health services in rural China: Lessons for Southeast Asia', in: Paul Cohen and John Purcal (eds), The political economy of primary health care in Southeast Asia, pp. 34-42. Canberra: Australian Development Studies Network, ASEAN Training Centre for Primary Health Care Development.

Querido, A. (1968). The development of socio-medical care in the Netherlands. London: Routledge and Kegan Paul. 
Rapport der Commissie (1908). Rapport der Commissie tot Voorbereiding eener Reorganisatie van den Burgerlijken Geneeskundigen Dienst. Batavia: Landsdrukkerij.

Roeder, O.G. (1971). Who's who in Indonesia: Biographies of prominent Indonesian personalities in all fields. Djakarta: Gunung Agung.

Schulte Nordholt, Henk (2004). De-colonising Indonesian historiography. Lund: Centre for East and South-East Asian Studies, Lund University. [Working papers in contemporary Asian studies 6.]

Sciortino, R. (1995). Care takers of cure: An anthropological study of health centre nurses in rural Central Java. Yogyakarta: Gadjah Mada University Press.

Soemedi (1940). 'De noodzakelijkheid van een goede opleiding niet alleen van de hygiene-mantri's en ander ondergeschikt personeel, doch ook van de artsen bij het Intensief Hygiëne Werk', in: Het Tweede Congres van de Vereeniging van Indonesische Geneeskundigen, gehouden op 22, 23, 24 en 25 Maart 1940 te Soerakarta, pp. 125-143. [Soerakarta: Vereeniging van Indonesische Geneeskundigen.]

Soetopo, Mas (1957). Intisari usaha kesehatan rakjat di Indonesia. [Surabaja: s.n.]

Sumbung, P.P. (1972). 'Tentang penempatan dokter', Majalah Kesehatan 34:58-59.

Tjokronegoro, S. (1956). 'Hubungan (affiliation) antara University of California dan Universitas Indonesia', in: Almanak Mahasiswa Kedokteran Djakarta, pp. 143-154. Djakarta: Senat Mahasiswa, Fakultas Kedokteran.

Tumbelaka, W.A.F.J. and M. Mardjono (1976). 'Pendidikan dokter Indonesia sejak 1950 hingga sekarang', in: Peringatan 125th pendidikan dokter di Indonesia, 1851-1976, pp. 69-76. Jakarta: Panitya Peringatan 125th Pendidikan Dokter di Indonesia.

Vickers, Adrian (2005). 'Why the 1950s are important to the study of Indonesia', paper presented at the Workshop 'Rethinking Indonesian Historiography: Decolonising Indonesian Historiography', Yogyakarta, 12-14 December.

VIG (Vereeniging van Indonesische Geneeskundigen) (1939). 'NIAS en GH', Medische Tribune 11:10-11.

Vogel,W.T. de (1917).Detaakvanden burgerlijkengeneeskundigendienstin NederlandschIndië. Amsterdam: Koninklijk Instituut voor de Tropen.

Zahar, S.B. (1938). 'Over de positie van de regentschapsarts', in: Het Eerste Congres van de Vereeniging van Indonesische Geneeskundigen gehouden op 24, 25 en 26 December 1938 te Semarang, pp. 56-73. [Semarang: Vereeniging van Indonesische Geneeskundigen.] 